\title{
15
}

\section{Comparing Roles and Rights of Indigenous Groups in Local Governance of Trepang Fisheries in Northern Australia and Eastern Indonesia}

Dirk J. Steenbergen, Gemma Wickens and Jackie Gould

\section{Introduction}

The trepang ${ }^{1}$ trade has historically sustained livelihoods in the Arafura Timor Seas (ATS) region and continues today (Adhuri, 2013b; Fox, 2000). The early trade was centred on the port of Makassar and undertaken predominantly by Makassarese, Bugis, Butonese and Bajau fishers based in southern Sulawesi (Clark \& May, 2013a). Now generally referred to as 'Macassans', these traders negotiated with the Indigenous landowners in Indonesia and Northern Australia for rights to access trepang stocks and sell the dried product to the Chinese market for hundreds of years (MacKnight, 1976). Such arrangements were typically organised around customary governance regimes on land and sea territory that recognised Indigenous ownership. Throughout the twentieth century, much of the region came under the jurisdiction of some form of central nationstate government, while international trade increasingly became subject

\footnotetext{
1 Trepang is the saleable product of sea cucumber, most commonly sandfish (Holothuria scabra), also referred to as teripang (in the Southeast Asia region) or bêche-de-mer (in the Pacific region).
} 
to control under various national and international trade agreements. The role of local Indigenous groups remains subject to complex political structures despite centrally legislated processes to determine rights and roles of local proprietary systems.

This chapter explores the national and regional influences that give shape to fisheries legislation in the Northern Territory (NT), Australia and eastern Indonesia and how these respectively impact on local access to small-scale fisheries (SSF). Using two cases of trepang fishery, this chapter shows how local actors become entangled in legislation that, while aiming to create fair and sustainable access to fisheries, creates a system of rights that can undermine the ability of local actors to engage in commercial and livelihood-sustaining activities. First, we set out the wider context of relevant policy development in Northern Australia and eastern Indonesia. We discuss the most important influences on fisheries policy design in each region and how these materialised into legislation. Second, we compare the Indigenous community at Warruwi in West Arnhem Land, Australia and Ohoiren in the Kei Islands of Moluccas Province, eastern Indonesia (see Figure 15.1) to show how local practices operate in relation to national policy. We observe that despite the vastly different socioeconomic and political settings, similar tensions exist between locallevel practice and policy design at various scales of government that reflect the challenges of balancing economic demands and need for sustainable environmental management.

This chapter draws from a review of SSF policy and the authors' ongoing engagement in qualitative research on local rights-based management over natural resources in Northern Australia (Gould, 2011, 2015) and eastern Indonesia (Steenbergen, 2013a, 2013b) through their respective research projects. ${ }^{2}$ For this study, enquiries were made on different actors' understanding of fisheries legislation and perceived opportunities and associated challenges, responsiveness of local practices to this legislation and how policy design progressed along particular agendas.

2 Steenbergen, 'Integrating Local Resource-Dependent Groups into Marine Resource Management in the Arafura Timor Seas Region' (NAMRA Postdoctoral research) (2014-2017); Wickens, 'Commercial Aboriginal Fisheries in the Northern Territory' (PhD project); Gould, 'Warruwi Fisheries and Aquaculture Knowledge Partnership Project' (Postdoctoral research). 

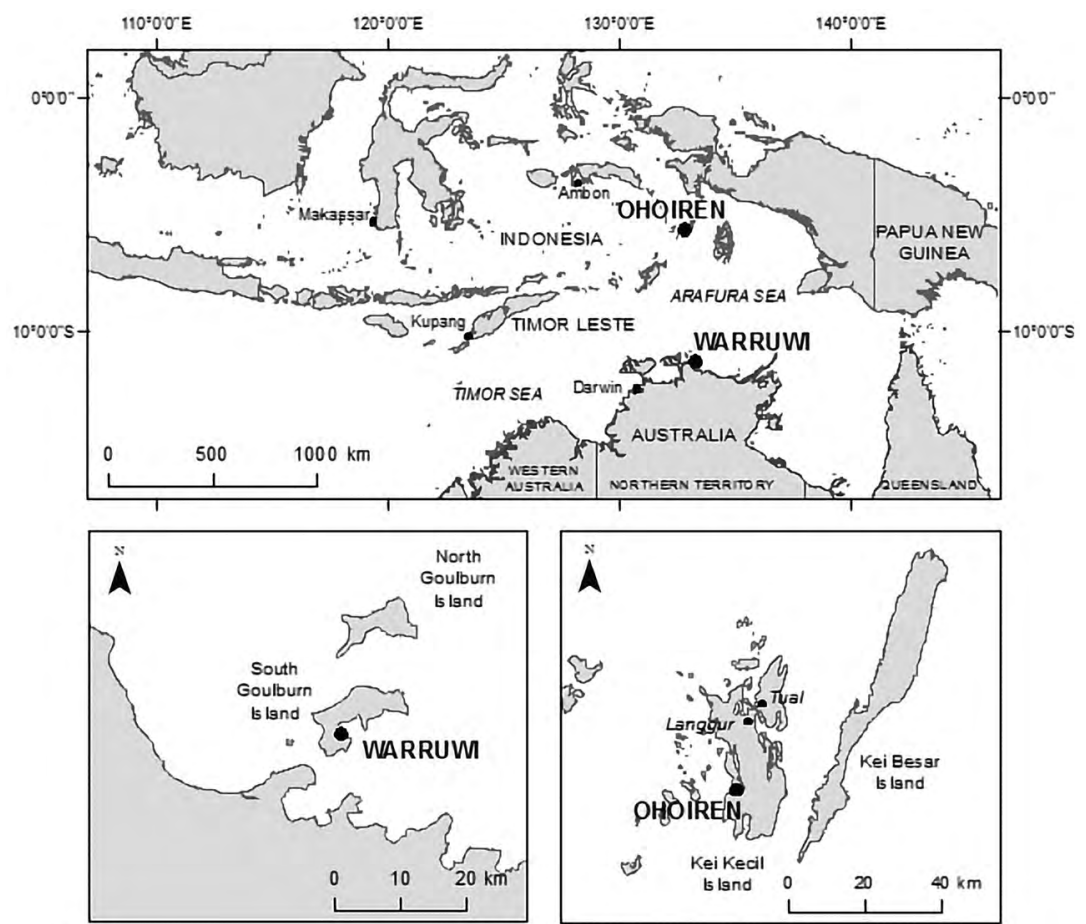

Figure 15.1: Map of the Arafura Timor Seas Region showing the two cases studies of Warruwi (West Arnhem Land, Northern Australia) and Ohoiren (The Moluccas, eastern Indonesia).

Source: Map created by the Research Institute for the Environment and Livelihoods, CDU, using Arc-GIS.

\section{The Wider Fisheries Policy Contexts}

Due to its remoteness, the ATS region was not subject to particularly active nation-state control for much of the twentieth century. In Northern Australian waters, lower levels of European settlement, compared to other parts of the coast, allowed local Indigenous people greater ability to continue the custodial role of their sea country, including significant subsistence fishing. However, regulation has, more recently, reduced their role in the commercial trade from resource owner to casual labourer. In eastern Indonesia, the early absence of fishery authorities also allowed the continuation of traditional resource management practices around communal inshore waters. However, increased central government rule 
and encroaching market actors mean these coastal communities no longer operate along singular governance frameworks. The following section outlines in further detail the major ways in which contemporary fisheries governance has come about in the two different contexts.

\section{Northern Territory, Australia}

Indigenous people have sophisticated rules governing the sea (Barber, 2010; Bradley \& Yanyuwa, 2007; Dillon, 2002; Nursey-Bray, 2005; Palmer, 1998; Palmer \& Brady, 1983; Peterson \& Devitt, 1997; Smyth \& Monaghan, 2004). Systems that designate land and sea country rights vary regionally, with those applying to the sea typically reflecting the complex tapestry of ancestral, ecological, sociocultural and economic values applicable to the land (Bagshaw, 1998; Barber, 2005; Morphy \& Morphy, 2006). Rights to resources are asserted through reference to kinship structures and totemic and spiritual relations. Coastal Indigenous groups retain significant cultural connections to marine areas and rely heavily on them for subsistence (Gray \& Altman, 2006; Henry \& Lyle, 2003).

In the NT, the land rights movement of the 1970s led to the passage of the Aboriginal Land Rights (Northern Territory) Act 1976 (ALRA) (see Figure 15.2). The ALRA allows Indigenous people a form of inalienable community freehold where land is held by designated Indigenous land trusts under regional land councils. Following the legal case of Blue Mud Bay, ${ }^{3}$ Indigenous land trusts, with land awarded to the mean low water mark under the ALRA, have the right to exclude people from their intertidal zone. Although the NT Government retains the property right to trepang and other marine resources and can control capture, use and sale, Aboriginal people can limit access to trepang habitats in inter-tidal waters across 85 per cent of the NT coastline. ${ }^{4}$ This is a significant portion of trepang habitat in the NT due to the large tides.

3 Northern Territory of Australia v Arnhem Land Aboriginal Land Trust [2008] HCA 29; 236 CLR 24; 82 ALJR 1099; 248 ALR 195 (30 July 2008).

4 The right to exclude parties from the inter-tidal zone has been a highly politicised issue in the Northern Territory, and in the main access to inter-tidal waters by commercial and recreational fishers has continued. Negotiations over how long-term access might be managed remain unresolved. For the latest iteration of access arrangements, see www.nlc.org.au/tidal-fishing. 


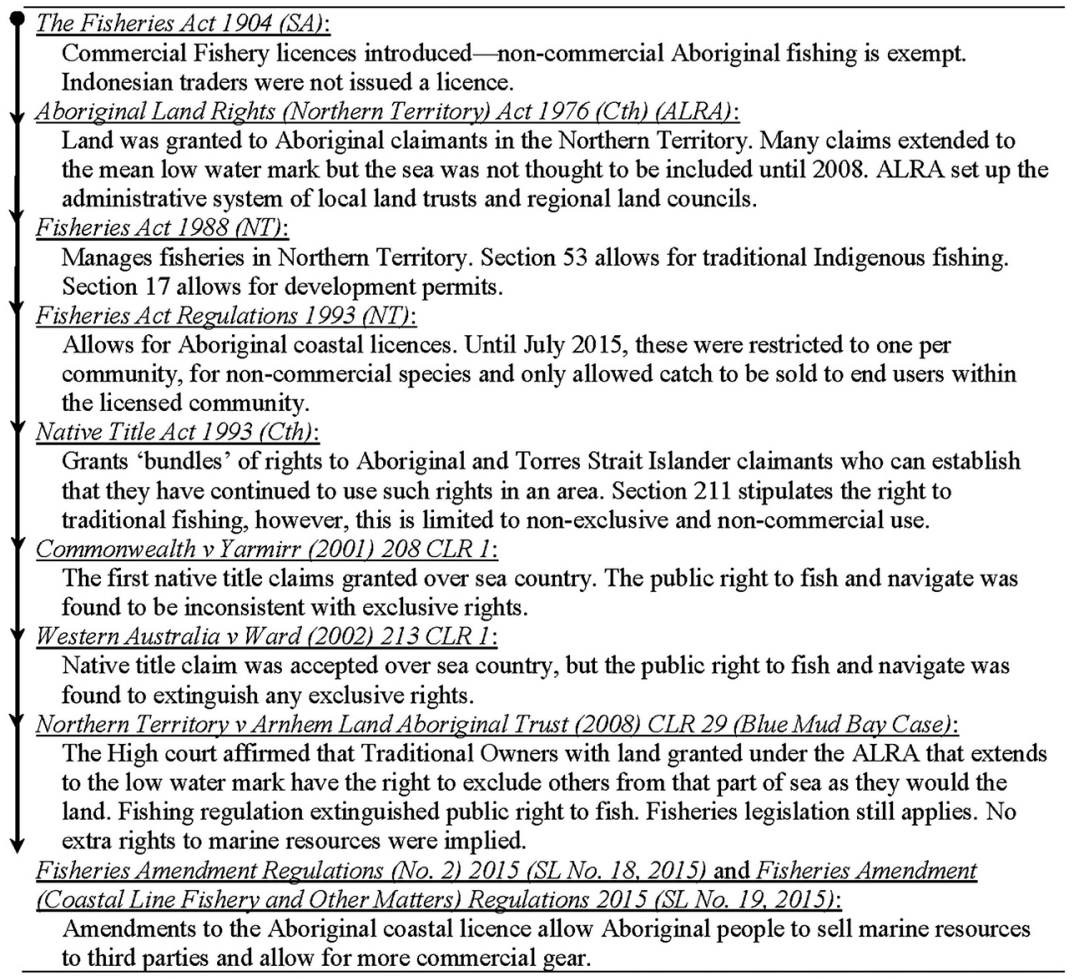

\section{Figure 15.2: Key legislation defining the rights of Aboriginal people to trepang in the Northern Territory.}

Source: Authors' research.

Beyond the mean low water mark, Indigenous Territorians have limited legal rights to their traditional waters. Section 211 of the Native Title Act 1993 (Cth) stipulates the right to traditional fishing; however, this is limited to non-exclusive and non-commercial use. ${ }^{5}$ Traditional fishing is also allowed under section 53 of the Fisheries Act 1988 (NT). The NT Fisheries Regulations $1993^{6}$ allow Indigenous people to apply for an Aboriginal coastal licence, which permits the limited sale and trade of aquatic resources. The regulations were amended in 2015 to remove many restrictions that had practically reduced rights to those already permitted

5 Exclusive rights to fish (property rights) were denied to native title claimants due to being inconsistent with the public right to fish (Commonwealth v Yarmir (2001) 208 CLR 1), extinguishing any exclusive right (Western Australia v Ward (2002) 213 CLR 1). A native title claim in the Torres Strait does include non-exclusive commercial rights (Akiba on behalf of the Torres Strait Regional Seas Claim Group v Commonwealth (2013) 300 ALR 1).

6 Part 11, Division 2. 
under section 53. Now, Aboriginal coastal licensees are permitted to sell fish to third parties and can use limited commercial gear, although most commercially valuable species are excluded from the licences. This builds on earlier trials carried out under development licences.

The Macassan trepang trade flourished across the north of Australia from at least the 1700s to 1907 (Clark \& May, 2013b), when regulations were enforced to support an Australian takeover of the industry (Macknight, 1969, 1976). For the first half of the twentieth century, scant landing reports suggest the catch was many times higher than recent times; however, this slowed after 1945 to zero (Department of Primary Industries and Regional Development, 2004). Interest was renewed by an NT Government financial viability study in 1986 (Department of Industries and Development, 1988), which led to six new licences being issued to established commercial fishers in 1992. The licensed areas were large and conditions of the licence ensured only those who were able to 'demonstrate sufficient experience and skills to safely and effectively

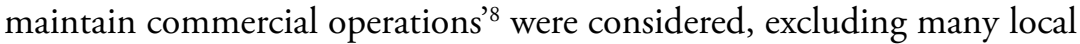
Indigenous people. Further financial incentives were added by merging fishing areas and making licences transferable in 1993. Consequently, all six licences are now owned by a single fisher based in Southern Australia, to the exclusion of local actors.

The NT trepang fishery is managed by NT Fisheries, part of the Department of Primary Industry and Resources (previously the Department of Primary Industry and Fisheries [DPIF]) (DPIF, 2016). Under division 13 of the NT Fisheries Regulations 1993, the licensed area extends three nautical miles from the high water mark and only manual collection is permitted. Most activity occurs along the Arnhem Land coast. In 1999, catch peaked at 250 tonnes, with a value of A $\$ 2.4$ million (DPIF, 1999). In 2012, this fell to 33 tonnes (DPIF, 2014), attributed to limitations in labour force rather than market failure (DPIF, 2013). In 1995, a fouryear research project commenced to record Indigenous knowledge of sandfish (a trepang species) and evaluate the possibility of creating an Indigenous trepang industry. Without Indigenous-held licences in place, Indigenous groups could not capitalise on the research. Instead, despite

7 Section 17 of the Fisheries Act 1988 (NT) and Part 8, Division 14 of the NT Fisheries Regulations 1993.

$8 \quad$ NT Fisheries Regulations 1993, Regulation 68.2(a) 
confidentiality agreements, the information was used by the sole trepang licensee to expand into the mapped areas and achieve record harvest and profits gains (Carter \& Hill, 2007). ${ }^{9}$

The extended period of Macassan contact had a significant impact on Indigenous economic and cultural dynamics (Berndt \& Berndt, 1954; Blair \& Hall, 2013). Some coastal communities express a strong desire to draw on this heritage to foster sustainable future livelihoods by engaging with the commercial trepang trade. While legislation recognising rights to sea country has progressed, it remains limited and has evolved separately to fisheries management regimes. The structure of the fisheries legislation is focused on balancing economic and environmental outcomes, with little consideration of social impacts, Indigenous cultural and historical connections or the ability of remote communities to engage in the industry. This acts to undermine access to potential benefits of resources by these groups.

\section{Eastern Indonesia}

Of the people employed in Southeast Asian capture fisheries, over half come from Indonesia, and the majority of Indonesia's rural population lives within $10 \mathrm{~km}$ of the coast (Asian Development Bank, 2014). This makes Indonesia's maritime space an important source of national and local income and cultural distinction. Contemporary fisheries policy, to which local fishers are subject in Indonesia, has been shaped by influential political agendas since the country's independence in 1945 (Muawanah et al., 2018). Early national laws and decrees that governed Indonesia's maritime space were primarily geared towards promoting economic development and securing national sovereign rule (see Figure 15.3). Indonesia's bountiful seas (like the ATS) were regarded primarily as economic assets that saw limits only in fishers' capacity to extract (Moss \& van der Wal, 1998; Novaczek et al., 2001). The first Fisheries Act (No. 9 of 1985) echoed this perspective, passing policies that ensured both subsistence and commercial access to marine resources.

9 This was prior to the Blue Mud Bay decision that could have prevented exploitation. 
National Law No. 4 of 1960 on defining Indonesia's territorial maritime boundaries as an archipelagic state [Djuanda Declaration]: Acknowledged the seas and all its resources as the property of the national government. National fisheries and coastal management consisted of rules and regulations administered across more than 20 ministries.

Ministerial Decree No. 607 of 1976 on fishing zonation under the Ministry of Agriculture:

Established initial zonation to partition (foreign) commercial and artisanal fishing access. Vessels $>5 \mathrm{GT}$ were allowed to fish only beyond the 3 NM coastal limit, while vessels $>25$ GT beyond the 4 NM limit and vessels $>100$ GT beyond the 5 NM limit.

Presidential Decree No. 39 of 1980 on trawling ban:

Imposed a ban on trawling along the Malacca Straits and off the north coast of Java (regarded the two most important fishing grounds) The ban extended nation-wide in 1981, except across the Arafura Timor Seas.

UN Convention of the Law of Sea (UNCLOS) of 1982:

Recognised Indonesian maritime borders, which led to institution of international boundaries under National Law No. 5 of 1983 on the exclusive economic zone (EEZ).

National Law No. 9 of 1985 on fisheries [Fisheries Act]:

Prohibited use of destructive fishing gear (e.g., explosive and poison fishing); designated inshore fishing to artisanal fishing subject to regulation (i.e., mesh sizes $>25 \mathrm{~mm}$ for reef fishing and $>60 \mathrm{~mm}$ for pelagic seine nets). Commercial access to fishing ground required license (i.e., foreign or domestic vessels $>30 \mathrm{GT}$ from national authority, 10-30 GT from provincial authority and $<10$ GT from district authority).

National Law No. 5 of 1990 on Conservation of Biological Natural Resources and Bcosustems [Biological Conservation Act]: Stipulated protection of habitats (i.e., priority habitats: mangroves, seagrass beds and coral reefs) and species (i.e., threatened species: 48 mammals [dugong, turtles, cetaceans, etc.], birds, crabs, shellfish and coral).

National Law No. 23 of 1997 on envinanmental management [Envinanmental Protection Act]:

Established framework for environmentally sustainable development and situating natural resource management under national government coordination.

Ministerial Decree No. 51 of 1997 on fishing aggregation device (FAD) installation and use under the Ministrv of Agriculture: Stipulated district responsibility over FADs within the $3 \mathrm{NM}$ coastal zone, provincial responsibility between 3-12 NM and beyond that under national fisheries directorate.

National Law No. 22 of 1999 on local government [Local Autonomy Act]: Stipulated revisions to coastal zonation for governance under Articles 4 and 10 (i.e., $<4$ NM coastal zone under district regulation, $<12$ NM under provincial regulation and beyond that under national legislation).

Presidential Decree No. 177 of 2000 on the organizational structure and task of ministries Formed and defined duty and function of Ministry of Marine Affairs and Fisheries (MMAF): assisted the president to conduct governance of marine affairs and fisheries. This included primarily implementing new devolved governance structures at provincial an district level, revising fisheries licensing and authorization, and governing the beyond the 12 NM coastal limit. MMAF (at respective levels: national, provincial and district) became responsible for: (i) Exploration, exploitation, conservation and manag ement of marine resources; (ii) Administrative function; (iii) Spatial planning; (iv) Law enforcement of local regulation and central legislation; (v) Support in Security issue, and (vi) Support in Defence.

National Law No. 32 of 2004 regarding regional government [Revised Regional Government Act]: Replaced previous Local Autonomy Act of 1999 and defined regional government to include provincial, district and city levels. Article 14 denoting full authority to regional government, except for functions/responsibilities attained by central government (the role of province decreased with most sectors devolving from national and provincial to district and city level).

National Law No. 31 of 2004 conceming fisheries [Revised Fisheries Act, enacted on 6 October 2004]:

Replaced former Fisheries Act of 1985 with focus on economic and environmental concerns, with particular mention on coral reef zones and their ecosystems. Article 7 provided MMAF the right to implement management measures and control fisheries activities (i.e. specified method or gear, determining maximum sustainable yield [MSY] or total allowable catch [TAC] for domestic and foreign fishers, prevented pollution and destructive fishing, and rehabilitation of resources and habitats).

Anticle 18 of National Law No. 32 of 2004 :

Emphasised management of natural resources and maintenance of environmental preservation (by regional govemment) pursuant of the law with similar maritime zonation division for governance.

National Law No. 27 of 2007 on management of coastal zones and small islands [Coastal Zones and Small Islands Act]: Established coordination, integration and consistency in management and planning decisions. Facilitated further decentralised community-based coastal management schemes by allowing concession rights to be granted to individuals (Indonesian citizens), adat communities and the private sector for up to 20 years, and could be used for extraction, conservation and tourism.

CTL-CFF leader's declaration signing of 2009: Initiated the CTI-CFF among six countries (Indonesia, Malaysia, Philippines, East Timor, Papua New Guinea and Solomon Islands). Driven by conservation lobby groups, with five main objectives: (i) Design and effectively manage priority seascapes; (ii) Apply ecosystem-based management of fisheries and other marine resources; (iii) Establish and effectively manage marine protected areas (MPAs); (iv) Achieve climate change adaptation measures; and (v) Improve threatened species status.

National Law No. 32 of 2009 on environmental management [Revised Envinonmental Protection and Management Act] Defined (marine) eco-regions, and stipulating improvement of legislation on the protection of marine ecosystems (previously not explicitly marine). Authorised central government to make and implement the policy on the protection of marine and coastal environment, coordinated by Ministry of Environment.

National Law No. I of 2014 on the Management of Coastal Areas and Small Islands [Revised Coastal Zones and Small Islands Act] Annulled coastal water concession provisions under National Law No. 27 of 2007 (following constitutional court ruling (No. 3/PUUVII/2010) in 2011). Article 20 noted that permissions to use local resources/areas may not interfere with traditional livelihood and use of coastal resources. Article 26A noted foreign investment in coastal resources must comprise public access, including fishing access.

\section{Legend}

Fisheries-oriented...

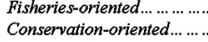

- Policy Shifts in Governance Centrality

- Policy Shifts Relevant to Marine NRM Governance

\section{Figure 15.3: National policy developments relevant to marine natural resource management in Indonesia.}

Source: Cribb and Ford (2009); Kusuma-Atmadja and Purwaka (1996); Novaczek et al. (2001); Satria and Matsuda (2004); Wever et al. (2012); De Alessi (2014); Rosen and

Olsson (2013). 
Following Indonesia's political reform ('reformasi') in 1999, responsibility for fisheries management was transferred to the newly established Ministry of Marine Affairs and Fisheries (MMAF). The change in Indonesia's political environment allowed for involvement of a wider set of stakeholders in processes of national policy design and regional collaboration. The already strong presence of conservation non-government organisations (NGOs) lobbying for environmental sustainability initiated a shift from an 'economic and exclusivity' driven fisheries agenda to one that included considerable attention for biological conservation.

The Biological Conservation Act (No. 5 of 1990) (see Figure 15.3) first incorporated formal policy that addressed the need to protect particular habitats and species (Novaczek et al., 2001) and saw the establishment of the first marine protected areas (MPAs). Their implementation lacked effective management and enforcement (Moss \& van der Wal, 1998; Persoon et al., 1996). Nevertheless, the environmental lobby campaigns continually gained a political voice and, almost two decades later, new revisions were passed into laws that addressed marineoriented environmental concerns (e.g. Environmental Protection and Management Act [No. 32 of 2009]). Capitalising on the momentum of the environmental NGO sector, Indonesia initiated the declaration of the Coral Triangle Initiative on Coral Reefs, Fisheries and Food Security $(\mathrm{CTI}-\mathrm{CFF})^{10}$ in 2009, which proposed a regional framework for implementation of marine conservation measures (Fidelman et al., 2012).

Alongside the various agendas working on Indonesia's fisheries policy, wider devolution of management and decision-making occurred that significantly altered the way fisheries were managed. Prior to 1999, official governing responsibilities were defined and refined per maritime zone (see Figure 15.3), although supreme ownership of and governance over all marine areas remained strongly centralised. After the 1999 government decentralisation, greater recognition developed for existing forms of local governance, acknowledging local customary law and management systems that, to varying degrees, still dictate coastal communities' access and use of marine resources (Satria \& Adhuri, 2010). Such customary management practices, typically applied to shallow inshore coastal zones, are based around tenure claims of particular social groups, are an integral part of local

10 The Coral Triangle covers an area marine scientists regard as the epicentre of global marine biodiversity, spanning the national territories of Indonesia, Malaysia, Philippines, East Timor, Papua New Guinea and the Solomon Islands. 
belief systems and have formed around longstanding cultivation practices of economically important marine resources (e.g. trepang and trochus). Government legislation and resource co-management planning initiatives increasingly seek to incorporate such customary systems into modern governance frameworks (Cohen \& Steenbergen, 2015; Steenbergen \& Visser, 2016). For example, under the national Coastal Zones and Small Islands Act (No. 27 of 2007) (see Figure 15.3), traditional custodians of particular territories were recognised and could be granted a mandate to sanction practices that impeded on local law (De Alessi, 2014). Such initiatives, although positive in that local tenure was recognised, formalised customary arrangements and moulded these to function in official government structures, leading to considerable loss of flexibility and fluidity of customary law. The law was later revised under No. 1 of 2014, which cancelled particular articles that formalised customary law (see Figure 15.3). As a result, in regions like the Kei Islands, coastal communities such as Ohoiren village face contemporary challenges in their management of trepang stocks that mirror both local and higherlevel political developments.

\section{Local Governance Practices Around Small-Scale Trepang Fisheries}

\section{Case Study 1: Trepang Fishery at Warruwi, Northern Territory}

Approximately 400 people live at Warruwi, on South Goulburn Island in Western Arnhem Land. Land and seas are held by patrilineal clans called nguya. Substantial management responsibilities and use rights are also conferred through maternal links. Additional less primary layers of rights and responsibilities flow from other sacred and secular relationships that underpin daily life (Gould, 2011). Livelihoods at Warruwi continue to have a seaward orientation. For many residents, their traditional estates are located within the coasts and seas on or around the island and nearby mainland. The marine environment remains an important source of food and plays an important role in social and cultural life, particularly in the passing on of ecological and cultural knowledge (Gould, 2011; Petheram et al., 2013). Resources are accessed, used and redistributed according to locally prescribed kinship and clan-based lines of responsibility. 
The Methodist mission, established at Warruwi in 1916, participated in the commercial harvesting of trepang and other seafoods. From oral history accounts, the mission involvement in the trepang trade continued until the 1950s or 1960s (Gould, 2011). Attempts to initiate a modern community-based trepang enterprise at Warruwi commenced in the early 2000s, when trepang management was discussed at community planning workshops and informally among community leaders. A business plan was developed in 2005 , focused on the development of a local hatchery and the sea-based cultivation of stock. This required an aquaculture licence and sea lease excised from the commercial wild harvest licence area. Attempts to attain the sea lease were unsuccessful due to a lack of scientific data that identified the area needed to establish a viable enterprise, thus stalling any immediate progress towards developing community-based enterprises at Warruwi.

At the time, little research into trepang breeding, growth dynamics, movement or preferred habitats had been conducted in Northern Australia. In recent years, however, interest in community-level enterprises from the commercial sector, NT Fisheries and an international aid agency has led to a suite of research projects being undertaken. This research has been complemented by projects at Warruwi focusing on building governance, infrastructural and technical capacity (Fleming, 2012), and on the commercialisation of other marine products like oysters, clams and fish (Fleming, 2015).

Although considerable technical data is now available, the licensing system used to manage the fishery assumes large-scale operations to the exclusion of Indigenous small-scale initiatives. As with other fishing sectors, substantial capital is required to purchase a licence, boats and the other equipment required to operate over a large licence area. Specialised technical skills are required to use and maintain this equipment, with costs and logistical issues inherent to remoteness presenting further challenges. To ensure financial viability, staff must work to a rigid framework with little room for considerations such as the need to care for young, elderly or sick family members, ceremonial obligations, and local prescriptions governing the allocation and use of resources collected from different areas. Warruwi's residents have exceptional knowledge of the local marine environment and aspirations commonly prioritise cultural and social resilience over commercial profit. Thus, a viable local industry would be one that allows this knowledge to be drawn on using low-technology 
inputs, with trepang collected by kinship-based groups from areas in which people have acknowledged traditional proprietary interests, and with products sold through a cooperative structure. ${ }^{11}$

Small-scale, wild-caught, commercial trepang fisheries would still require, under current legal structures, a licence to be attained on the free market from the sole licensee who may be unwilling to sell such a right and is likely to demand a prohibitively high price. Indigenous communities can harvest trepang under agreement with the licence holder, selling their product exclusively to the licensee. Two trial harvests using such a model were undertaken in 2015 and 2017. Although the trials were successful, this model does not allow any community participation in the industry beyond the harvesting stage of production. There remains the possibility of obtaining an aquaculture licence and sea lease for ranching trepang. As this would see the licence area excised from the wild harvest licence area, it requires political will to favour the social and cultural interests of Indigenous people over the corporate interests of commercial fishers. Finally, the recent changes to the Aboriginal coastal licence regime gives the Director of Fisheries discretionary powers regarding whether trepang collection is permitted. At the time of fieldwork, five licences had been issued, although none requested limited local collection and sale of trepang. ${ }^{12}$ There are few opportunities to leverage sea rights beyond the inter-tidal zone to raise capital. Overall, the current legislative regime creates a range of pathways towards SSF development, but each incurs insurmountable barriers for Indigenous communities such as Warruwi.

\section{Case Study 2: Trepang Fishery at Ohoiren, Eastern Indonesia}

Ohoiren is located along the western coast of Kei Kecil Island, with a small population of 567 people spread across about 120 households (Kecamatan Kei Kecil Barat, 2010). People sustain livelihoods through diverse engagement in small-scale agriculture, subsistence fishing and artisan activities (e.g. iron smithing, weaving and boat building). Collective income-generating activities are important and include trepang fisheries. These fund communal activities often linked to the village's Catholic church (e.g. restoration/maintenance of church grounds).

11 The Yagbani Aboriginal Corporation was established at Warruwi in 2011, in part for this purpose.

12 The inclusion of trepang in any Aboriginal coastal licence would have similar commercial implications to the creation of an aquaculture licence and, therefore, is likely to be similarly controversial. 
Ohoiren's customary resource management and tenure regimes developed from a long history of trepang cultivation across Kei's coastal communities (Thorburn, 2000). Communal territory (petuanan kampung) is typically overseen by a local traditional 'lord of the land' (tuan tanab) (Adhuri, 2013a; Laksono, 2002). Customary marine resource management systems developed locally within the cadres of local ownership. These customary systems, although more recently altered through co-management initiatives seeking to build on both customary and science knowledge bases (see also Cohen \& Steenbergen, 2015), still determine how resources are accessed locally. As a result, local fishers typically operate loosely within what is defined in national policy, particularly given the limited capacity for central enforcement. ${ }^{13}$

In 2004, residents of Ohoiren started collaborating with an Indonesian conservation NGO in response to local concerns regarding the continued withering of customary practices and increased infringements by outsiders extracting resources. The collaboration promoted sustainable marine resource management practices through strengthening traditional governance. Village regulations were formulated as an extension of existing traditional laws to control the cultivation, harvest and sales of trepang and were enforced locally by community groups. The NGO identified opportunity under the Coastal Zones and Small Islands Act to provide legal subdistrict recognition of these village regulations, which allowed Ohoiren to legally sanction infringements on their trepang access regulations. Moreover, as part of the collaboration with the NGO, particular small marine areas were allocated as permanent no-take zones to form trepang sanctuaries. Regular trepang monitoring activities were conducted within and outside these no-take zones to supposedly inform when and how much could be harvested at any one time. These local control and management structures influenced how local management was conducted. Entrepreneurial connections of the NGO enabled Ohoiren to obtain official legal recognition of local ownership and village resources use regulations. ${ }^{14}$

13 Throughout eastern Indonesia, documented cases exist of outside fishers subjected to custodian action by residents based on locally perceived rights as custodians of land and sea (Steenbergen, 2013a, 2013b).

14 Ohoiren was one of only two communities in the subdistrict to have gained such legal recognition of village regulations. Both obtained this through collaboration with the same NGO. 
Simultaneously, but distinct from these local developments, a larger MPA was gazetted in the western Kei Islands as a direct result of increased conservation-oriented projects in the last decade. An international conservation NGO responsible for driving the implementation of this larger MPA initially had commenced a participatory planning strategy with local communities. However, these efforts failed to capture local interest or build on traditional governance. Several communities, including Ohoiren, eventually withdrew from collaboration with the international NGO. The NGO, however, persisted in its endeavour to establish an MPA and shifted strategy towards gaining district political leverage that eventually facilitated its implementation. So, although this MPA encompasses communal territories that had pre-existing management regimes in place, planning and implementation resulted from the international conservation NGO's negotiations with local government with very low community participation. Among community fishing groups, such as in Ohoiren, little was known of this gazetting or what implications it had for local practices. Ironically, the opportunities in legislation that officially recognised Ohoiren's traditional village regulations were now applied by other actors to recognise superseding laws under the MPA and inadvertently undermined the recently established local authority.

Considering the developments in and around Ohoiren, it is clear that Indigenous fishers operate in and between plural governing structures: 1) official government policy imposed through district authorities (e.g. the establishment of the large MPA), 2) traditional tenure regimes that are part of local customary law systems and, midway between these, 3) co-management frameworks that attempt to develop management systems that draw from both customary and sciencebased practices (e.g. Ohoiren's trepang management village regulations). At various instances in their local livelihood practices, Indigenous fishers contradict one or several of these governing frameworks. For example, the extraction of trepang for commercial sales as managed under the village co-management scheme breaches the resource protection regulations of the MPA regulations. Similarly, annual fishing gear handouts from the fisheries department to local fishers as a means to bolster local production and food security was perceived locally to contradict other restrictive fishing policies endorsed by the same government department.

The complexity and inadequate dissemination of higher-level policy meant Indigenous fishers tended to adhere to more familiar regulations, which often involved rules developed locally under co-management 
arrangements or that were part of customary law. In cases where fishers violated official district-level regulations, such as larger MPA regulations, they were often unaware they were acting illegally. Consequently, the governance frameworks formed in part by strategic interest groups from the conservation sector clearly steered what kinds of measures were implemented. However, without adequate information sharing and participation, mechanisms also significantly fell short in advancing desirable local practice.

\section{Discussion}

In both locales, historic engagement around resource use, between Indigenous groups and outsiders, have been sidelined during centralisation of political and economic power following nation-state building agendas over the twentieth century. The contemporary settings in both Northern Australia and eastern Indonesia sees involvement of powerful national and international actor groups engaging with, or at least active in the same areas as, Indigenous groups who have little political leverage on their own. Recent trends towards recognising traditional proprietary systems in both countries create legislative contradictions regarding access to and use of marine areas and resources.

At Warruwi, the development of fisheries legislation has effectively come to favour larger non-local corporate interests and excludes remote Indigenous community small-scale participation in the trepang industry. Land rights legislation has emerged separately and has not impacted on the ways in which extractive rights to marine resources are allocated. The contemporary economic marginality of remote communities in the context of a regional economy based on large-scale projects leave remote communities with few commercial or political assets to leverage in their attempts to build sustainable futures (Howitt, 2010). Substantial investments have been made by the community, a partnering aid agency and within NT Fisheries to develop the technical and governance capacities required to establish a small-scale trepang enterprise, ${ }^{15}$ but these efforts have, to date, failed to impact on the higher-level political structures that favour existing large commercial interests in the designation of land and sea rights and fisheries management regimes.

15 We note these sit alongside investments by the commercial licence holder into trepang ranching research and development. 
In Ohoiren, the development of policy and legislation at various levels has brought forth both restrictive and supportive regulations and created a complex arena of legal pluralism. Thus, local governance arrangements based on customary laws exist in one form or another alongside central government policy and legislation. Centrally managed MPAs, for example, are being established over waters that include communal areas where local no-take zones have been independently designated by communities. Communities like Ohoiren, in their collaboration with the NGO, have been able to partially navigate these complexities and secure their claims over tenure and local ownership by having their customary law recognised in state law. In such cases, communities have benefited from collaborations with well-informed and well-connected NGOs-the community in Ohoiren, for example, was able to curb potential encroachments on its right to access and manage resources through passing of higher-level legislation. The large majority of coastal communities in the wider eastern Indonesian context do not have access to facilitating agents. In such cases, lack of political entrepreneurship leaves communities functioning somewhere in the middle between official central state and district law on one hand and local customary law on the other. So, although national policy presents opportunity for communities to play a more significant role, without trusted and well-informed politically facilitating agents in place, local actors appear unlikely to capitalise on such opportunities.

In both cases, divergent discursive trajectories appear to inform legislation, impacting the way local Indigenous communities go about using resources. In the NT, fisheries legislation aims to regulate the extraction of resources in a sustainable manner. Land and sea rights legislation has, in more recent times, emerged to partially recognise Indigenous entitlements to the access and use of country. Although this latter legislation has, to some degree, limited the rights of those holding commercial fisheries licences (allowing potential control over access to the inter-tidal zone), it has not allowed Indigenous communities to enter into spaces vacated by the commercial sector (by allowing access to the marine resources). Additionally, with no formal platform for the integration of Indigenous voices into the management of the NT's fisheries, Indigenous systems of resource allocation and use are not able to inform wider extractive and environmental management regimes. In eastern Indonesia, policy brought forward through the MMAF subjects resource users both to measures that bolster rural coastal economic development and measures that restrict capture fisheries. The suite of conflicting measures 
distort local understandings of what sustainable resource management means-namely, balancing interests of economic rural development and environmental protection.

Reflecting on these findings, it is important to consider what the implications are for wider narratives that dictate development in the two case studies. In the push to 'Develop the North', it is imperative that the Australian and NT governments look beyond the rhetoric that is giving direction to legislative change. Creating tensions between stakeholders, without real benefits accruing to either, does little to stimulate economic or environmental outcomes. The recognition of Indigenous rights to control access to inter-tidal zones has the potential to create economic benefits for remote communities in the form of royalty schemes. However, NT governments may wish to consider taking the additional step of developing policies that favour small-scale extractive (as opposed to mere access) rights to marine resources, if their stated agenda of promoting Indigenous community development is genuine. The recent changes to the Aboriginal coastal licensing regime represent a significant move in this direction. They create a policy space that allows local SSF business to be developed, although it is too soon to see whether the Director of Fisheries will use their discretionary powers under this regime to do sofor example, by allowing the collection of trepang at Warruwi.

In eastern Indonesia, SSF policy narratives are brought forward under the regional multilateral partnership of the CTI-CFF to focus on local food security and environmental sustainability. Such policy narratives need to translate locally to function in or with local customary governing systems, rather than simply acknowledging their existence while implementing parallel SSF management schemes (see also Courtney et al., 2017; van Nimwegen, 2017). Opportunity for recognition in government law already exists, as is evident in Ohoiren's case where local tenure rights were endorsed by subdistrict authority. However, to prevent this process of local ownership recognition becoming a reactionary measure to fears of higher-level (restrictive) policy developments, both governance contexts require effective information and knowledge exchange. Implementing enduring information-sharing platforms across policy levels may provide a catalyst for developing understanding across the multi-scaled fisheries frameworks that Ohoiren, Indonesia and ATS regions are all governed by. 
A notable priority under the NT Government's development agenda is to foster development in remote communities. Rights-based management over natural resources offers the opportunity to enhance livelihoods and establish effective local governance capacity. Support for SSF in the NT is emerging but underdeveloped; however, in drawing from the above discussion on legal recognition of local tenure claims in the eastern Indonesia case, lessons can be learned in terms of the sort of complexity and potential challenges of plurality involved in establishing legislative recognition of local authority structures.

\section{Conclusion}

In the context of wider regional development narratives aspiring to address local socioeconomic development challenges while also achieving environmental sustainability, local resource user groups clearly stand to play an important role. However, as the case studies have shown, there are particular voices that remain unheard or are inadequately responded to. For effective policy to emerge in remote Indigenous communities, rights-based policy design processes must secure socially and politically just outcomes. Particularly, the position of local Indigenous peoples in negotiations over resource access with powerful competing industry or public sector interest groups needs strengthening. Contemporary governance design processes proceed with too little genuine input from local customary owners of particular land or seascapes who claim value of a place for its cultural capital and as a primary source of livelihood and living environment. Instead, such processes appear more responsive to larger economic development plans (e.g. NT's 'Developing the North') and powerful conservation lobby movements (e.g. CTI-CFF).

The need for more inclusive processes refers to planning, design and implementation stages that extend beyond local spheres into multiple policy scales. Tools and mechanisms facilitating effective rights-based resource management on the ground, as seen in eastern Indonesia, must be made to fit within existing sociopolitical arenas. Such arenas have existing forms of local governance, strong social hierarchies, legacies of past development and strong competing interests from other stakeholders, which all affect how resources are accessed. Establishing channels of information sharing, integrating adequate checks and balances in management design and building platforms for suitable 'institutional bricolage' (Cleaver, 2012) to 
take place at interfaces between different stakeholder groups may provide the necessary exchange and dual-way understanding to address conflicting governance structures or co-option of resources by powerful groups over weaker groups.

Given a complex legislative environment with many stakeholders extant across varied spatial scales, the need for an effective balance between social, economic and environmental prerogatives is fundamental but challenging. Without unfairly compromising the legitimate interests of existing commercial sectors, Indigenous communities require access to the legislative spaces necessary for engaging with the national and global economies. In considering legislative reforms in the context of the Northern Development Agenda, thought must be given to the adverse unintended consequences of policy implementation, such as occurs with the interaction of fisheries management and land rights regimes. Enabling Indigenous economic development is a prerogative for governments and Indigenous communities alike. Progress is more likely to happen through the resolution of tensions created by contradictory legal regimes than through the retraction of land and sea rights.

\section{References}

Adhuri, D. S. (2013a). Selling the sea, fishing for power: A study of conflict over marine tenure in Kei Islands, Eastern Indonesia. Canberra, ACT: ANU E Press. doi.org/10.22459/SSFP.02.2013

Adhuri, D. S. (2013b). Traditional and 'modern' trepang fisheries on the border of the Indonesian and Australian fishing zones. In M. A. Clark \& S. K. May (Eds), Macassan history and heritage journeys, encounters and influences (pp. 183-203). Canberra, ACT: ANU E Press. doi.org/10.22459/MHH.06.2013

Asian Development Bank. (2014). Economics of fisheries and aquaculture in the Coral Triangle. Mandaluyong City, Philippines: Asian Development Bank. Retrieved from www.adb.org/sites/default/files/publication/42411/economics-fisheriesaquaculture-coral-triangle.pdf

Bagshaw, G. (1998). Gapu Dhulway, Gapu Maramba: Conceptualisation and ownership of saltwater among the Burarra and Yan-nhangu peoples of northeast Arnhem Land. In N. Peterson \& B. Rigsby (Eds), Customary marine tenure in Australia (pp. 247-283). Sydney, NSW: University of Sydney Press. 
Barber, M. (2005). Where the clouds stand: Australian Aboriginal relationships to water, place, and the marine environment in Blue Mud Bay, Northern Territory (unpublished doctoral thesis). ANU, Canberra, ACT.

Barber, M. (2010). Coastal conflicts and reciprocal relations: Encounters between Yolngu people and commercial fishermen in Blue Mud Bay, north-east Arnhem Land. The Australian Journal of Anthropology, 21, 298-314. doi.org/ 10.1111/j.1757-6547.2010.00098.x

Berndt, R. \& Berndt, C. (1954). Arnhem Land: Its history and its people. Melbourne, Vic.: Cheshire.

Blair, S. \& Hall, N. (2013). Travelling the 'Malay Road': Recognising the heritage significance of the Macassan maritime trade route. In M. Clark \& S. May (Eds), Macassan history and heritage journeys, encounters and influences (pp. 80-100). Canberra, ACT: ANU E Press. doi.org/10.22459/MHH.06.2013

Bradley, J. \& Yanyuwa, F. (2007). Barni-Wardimantha Awara Yanyuwa sea country plan. Retrieved from Mabunji Aboriginal Resource Association.

Carter, J. \& Hill, G. (2007). Indigenous community-based fisheries in Australia. Journal of Environmental Management, 85(4), 866-875.

Clark, M. \& May, S. (2013a). Macassan history and heritage: Journeys, encounters and influences. Canberra, ACT: ANU E Press. doi.org/10.22459/MHH.06.2013

Clark, M. \& May, S. (2013b). Understanding the Macassans: A regional approach. In M. Clark \& S. May (Eds), Macassan history and heritage: Journeys, encounters and influences (pp. 1-18). Canberra, ACT: ANU E Press. doi.org/10.22459/MHH.06.2013

Cleaver, F. (2012). Development through Bricolage: Rethinking institutions for natural resource management. New York, NY: Routledge.

Cohen, P. J. \& Steenbergen, D. J. (2015). Social dimensions of local fisheries co-management in the Coral Triangle. Environmental Conservation, 42(03), 278-288. doi.org/10.1017/S0376892914000423

Courtney, C. A., Pomeroy, R., De Alessi, M., Adhuri, D., Yuni, C. \& Halim, A. (2017). Marine tenure and small-scale fisheries: Learning from the Indonesia experience. Retrieved from land-links.org/wp-content/uploads/2018/03/USAID _Land_Tenure_TGCC_Indonesia_Marine_Tenure_Report_Updated.pdf

Cribb, R. B. \& Ford, M. (2009). Indonesia beyond the water's edge: Managing an archipelagic state. Singapore: Institute of Southeast Asian Studies. 
De Alessi, M. (2014). Archipelago of gear: The political economy of fisheries management and private sustainable fisheries initiatives in Indonesia. Asia \& the Pacific Policy Studies, 1(3), 576-589. doi.org/10.1002/app5.40

Department of Industries and Development. (1988). Beche-de-mer (trepang) harvesting preliminary economic feasibility study. Northern Territory: DID, Division of Primary Production.

Department of Primary Industry and Fisheries (DPIF). (1999). Fishery status reports 1999. Retrieved from dpir.nt.gov.au/_data/assets/pdf_file/0012/ 233121/fr55.pdf

Department of Primary Industry and Fisheries (DPIF). (2013). Annual report 2012-2013. Retrieved from industry.nt.gov.au/_data/assets/pdf_file/0005/ 227840/dpif_ar1213.pdf

Department of Primary Industry and Fisheries (DPIF). (2014). Fishery status reports 2012. Retrieved from dpif.nt.gov.au/_data/assets/word_doc/0011/ 233678/fr113_compat.docx

Department of Primary Industry and Fisheries (DPIF). (2016). Status of key Northern Territory fish stocks 2014. Retrieved from dpif.nt.gov.au/_datal assets/pdf_file/0006/366117/FR115.pdf

Department of Primary Industries and Regional Development. (2004). Fishery status reports—2003. Retrieved from hdl.handle.net/10070/222882

Dillon, R. (2002). Seeing the sea change and Indigenous sea rights. Maritime Studies, 2002(123), 12-16.

Fidelman, P., Evans, L., Fabinyi, M., Foale, S., Cinner, J. E. \& Rosen, F. (2012). Governing large-scale marine commons: Contextual challenges in the Coral Triangle. Marine Policy, 36(1), 42-53.

Fleming, A. (2012). Sea ranching of sandfish in an Indigenous community within a well-regulated fishery (Northern Territory). Retrieved from coastfish.spc.int/ doc/coastfish_docs/Meetings/PPT19_Fleming.pdf

Fleming, A. (2015). Improving business investment confidence in culture-aligned Indigenous economies in remote Australian communities-A business support framework to better inform government programs. International Indigenous Policy Journal, 6(3). doi.org/10.18584/iipj.2015.6.3.5

Fox, J. J. (2000). Maritime communities in the Timor and Arafura Region: Some historical and anthropological perspectives. In S. O'Conner, P. Veth \& A. A. Balkema (Eds), East of Wallace's Line: Studies of past and present maritime cultures of the Indo-pacific region (pp. 337-356). CRC Press. 
Gould, J. L. (2011). Being in the black: The business of development in Northern Australia (unpublished honours thesis). Charles Darwin University, Darwin, NT.

Gould, J. L. (2015). Caught in the tides: The (re)development of a trepang industry at Warruwi, Northern Territory. Reviews in Fish Biology and Fisheries, 26(4). doi.org/10.1007/s11160-015-9400-3

Gray, M. \& Altman, J. (2006). The economic value of harvesting wild resources to the Indigenous community of the Wallis Lake Catchment, NSW. Family Matters, 75, 24-33.

Henry, G. \& Lyle, J. (Eds). (2003). The national recreational and Indigenous fishing survey. Retrieved from eprints.utas.edu.au/2526/1/Henry_Lyle_ Nationalsurvey.pdf

Howitt, R. (2010). Sustainable Indigenous futures in remote Indigenous areas: Relationships, processes and failed state approaches. GeoJournal, 77(6), 817828.

Kecamatan Kei Kecil Barat. (2010). Kei Kecil Barat Dalam Angka [Western Kei Kecil in Numbers]. Retrieved from Central Board of Statistics Indonesia (Badan Pusat Statistik, BPS)—Maluku Tenggara District.

Kusuma-Atmadja, M. \& Purwaka, T. H. (1996). Legal and institutional aspects of coastal zone management in Indonesia. Marine Policy, 20(1), 63-86. doi.org/ $10.1016 / 0308-597 x(95) 00034-4$

Laksono, P. M. (2002). The common ground in the Kei Islands: Eggs from one fish and one bird. Yogyakarta, Indonesia: Galang Press.

Macknight, C. C. (1969). The Macassans: A study of the early trepang industry along the Northern Territory coast (unpublished doctoral thesis). ANU, Canberra, ACT.

MacKnight, C. C. (1976). The voyage to Marege': Macassan trepangers in northern Australia. Melbourne, Vic.: Melbourne University Press.

Morphy, H. \& Morphy, F. (2006). Tasting the waters: Discriminating identities in the waters of Blue Mud Bay. Journal of Material Culture, 11(1-2), 67-85. doi.org/10.1177/1359183506063012

Moss, S. M. \& van der Wal, M. (1998). Rape and run in Maluku: Exploitation of living marine resources in eastern Indonesia. Cakalele, 9(2), 85-97. 
Muawanah, U., Yusuf, G., Adrianto, L., Kalther, J., Pomeroy, R., Abdullah, H. \& Ruchimat, T. (2018). Review of national laws and regulation in Indonesia in relation to an ecosystem approach to fisheries management. Marine Policy, 91, 150-160. doi.org/10.1016/j.marpol.2018.01.027

Novaczek, I., Sopacua, J. \& Harkes, I. (2001). Fisheries management in Central Maluku, Indonesia: 1997-98. Marine Policy, 25(3), 239-249.

Nursey-Bray, M. (2005). Having a yarn: Engaging with Indigenous communities in natural resource management. Paper presented at the International Conference on Engaging Communities. Retrieved from citeseerx.ist.psu.edu/viewdoc/ download?doi=10.1.1.574.7680\&rep=rep1 \&type=pdf

Palmer, K. (1998). Customary marine tenure at Groote Eylandt. In N. Peterson \& B. Rigsby (Eds), Customary marine tenure in Australia (pp. 227-245). Sydney, NSW: University of Sydney Press.

Palmer, K. \& Brady, M. (1983). A report prepared in support of an application to control entry onto seas adjoining Aboriginal land. Prepared on behalf of the Minjilang Aboriginal Community and other traditional owners. Darwin, NT: Northern Land Council.

Persoon, G. A., de Iongh, H. \& Wenno, B. (1996). Exploitation, management and conservation of marine resources: The context of the Aru Tenggara marine reserve (Moluccas, Indonesia). Ocean and Coastal Management, 32(2), 97-122.

Peterson, N. \& Devitt, J. (1997). A report in support of an application for recognition of the native title to areas of sea by the Mangalara, Mandilarri-Ildugij, Murran, Gadura, Mayarram, Minga and Ngaynjaharr of the Croker Island region. Northern Land Council.

Petheram, L., Fleming, A., Stacey, N. E. \& Perry, A. (2013). Indigenous women's preferences for climate change adaptation and aquaculture development to build capacity in the Northern Territory. National Climate Change Adaptation Research Facility.

Rosen, F. \& Olsson, P. (2013). Institutional entrepreneurs, global networks, and the emergence of international institutions for ecosystem-based management: The Coral Triangle initiative. Marine Policy, 38, 195-204. doi.org/10.1016/ j.marpol.2012.05.036

Satria, A. \& Adhuri, D. S. (2010). Pre-existing fisheries management systems in Indonesia, focusing on Lombok and Maluku. In K. Ruddle \& A. Satria (Eds), Managing coastal and inland waters: Pre-existing aquatic management systems in Southeast Asia (pp. 31-55). Dordrecht, Heidelberg, London and New York: Springer Science and Musiness Media. 
Satria, A. \& Matsuda, Y. (2004). Decentralization of fisheries management in Indonesia. Marine Policy, 28(5), 437-450.

Smyth, D. \& Monaghan, J. (2004). Living on saltwater country: Review of literature about Aboriginal rights, use, management and interests in northern Australian marine environments. Hobart, Tas.: National Oceans Office.

Steenbergen, D. J. (2013a). Negotiating the future of local 'backwaters': Participatory marine conservation on small islands in eastern Indonesia (unpublished doctoral thesis). Murdoch University, Perth, WA.

Steenbergen, D. J. (2013b). The role of tourism in addressing illegal fishing: The case of a dive operator in Indonesia. Contemporary Southeast Asia, 35(2), $188-214$.

Steenbergen, D. J. \& Visser, L. E. (2016). Caught between mediation and local dependence: Understanding the role of non-government organisations in comanagement of coastal resources in eastern Indonesia. Anthropological Forum, 26(2), 115-137. doi.org/10.1080/00664677.2016.1148012

Thorburn, C. C. (2000). Changing customary marine resource management practice and institutions: The case of Sasi Lola in the Kei Islands, Indonesia. World Development, 28(8), 1461-1479.

van Nimwegen, P. (2017). Shifting waters-Indonesia's dynamic marine protected area policy seascape (unpublished Master's thesis). Murdoch University, Perth, WA.

Wever, L., Glaser, M., Gorris, P. \& Ferrol-Schulte, D. (2012). Decentralization and participation in integrated coastal management: Policy lessons from Brazil and Indonesia. Ocean \& Coastal Management, 66(2012), 63-72. doi.org/ 10.1016/j.ocecoaman.2012.05.001 
This text is taken from Leading from the North: Rethinking Northern Australia Development, edited by Ruth Wallace, Sharon Harwood, Rolf Gerritsen, Bruce Prideaux, Tom Brewer, Linda Rosenman and Allan Dale, published 2021 by ANU Press, The Australian National University, Canberra, Australia. 